the Azande and the demand for it is increasing. Close to Sakure and at Nzara (and, in the future, at other sites) oil-palm plantations have been planted and these will produce palmoil for helping in soap production and for supply to the Azande for domestic purposes. Production of coffee is also being investigated. The oil-mill will deal with any groundnuts or simsim which may be produced surplus to domestic needs. The dairy herd produces milk for the town, and a beef herd, shortly to be enlarged, produces meat in an otherwise meatless area.

The trading section of the Board has developed side by side with the production section, but over a wider field. Briefly, the functions of this section are to market the products of the Board, and to undertake wholesale and retail trade in other locally produced and imported articles. Its objectives are to develop a true sense of money values in a community which was not used to a money economy and which was liable to exploitation by private traders; to provide useful trade goods of good quality and at low prices; and to train Southern Sudanese traders. Shops have been set up in many districts of Equatoria and Bahr el Ghazal Provinces and many Southern Sudanese have been trained and are being trained as shopkeepers. This section may provide capital for those who have been trained and wish to set up shop, and function as a wholesaler to some of those who have shops.

This then was the setting and background to a simple ceremony held on 8 March at Nzara, to mark the completion of the preliminary stage of construction and the start of industrial production in Zandeland. It is hoped that it marks a new era in Zandeland. Nzara and its factories are a means to an end. They mark the start of economic development and are the bases on which what has been called the Zande Scheme rests. The Zande Scheme aims at the end, which is the social emergence and economic stability of the Azande.

(Sudan News and Features, A. G. McCall)

\title{
Belgian Congo: Government Grants for Protestant Schools
}

Since 1948 the Protestant Missions in the Belgian Congo have been able, under certain conditions, to receive Government aid for their educational work and in this respect have been placed on an equal footing with the Roman Catholic Missions. Prior to this date only Roman Catholic or 'National' schools were eligible for official inspection, status, and financial and other assistance.

To qualify for official status and Government grants Protestant Missions must first be recommended by the Conseil Protestant du Congo and sign a Government Convention. The teaching staff, European and African, in order to receive State subsidies, must be qualified to teach. To give clear guidance to the missions, Catholic and Protestant, the Government published three brochures in 1948 on L'Organisation de l'Enseignement libre subsidié pour Indigènes avec le concours des societés de missions chrétiennes.

A period of five years was granted to the missions to conform to the new requirements, during which financial and other valuable help has been given to those schools which applied for it and satisfied the Government inspectors. This transition period is likely to be prolonged.

In order to qualify for Government recognition, educational missionaries who are not of Belgian nationality are required to spend at least twelve months in Belgium. They have to know French. They are expected to attend regularly a Belgian 'école normale ou supérieure' for six months and then follow a Colonial Course and pass an examination on the subjects taught. French classes and the Colonial courses are organized by the Colonial Department with the help of excellent professors. Missionaries with a good knowledge of French can obtain exemption from the French classes but not from the examination. Only those who pass the French examination are allowed to take the Colonial Courses. 
The subjects taught during the Colonial Courses are as follows : Hygiène, Devoir colonial, Base des langues bantoues, Aperçu général géographique et politique, Histoire: a) de Belgique, b) du Congo, Organisation politique au Congo Belge, Institutions belges de Belgique, Etat civil, Régime religieux, Législation foncière, Législation sociale, Principes généraux coloniaux et Ethnographie.

The diplomas and certificates of those who successfully pass the examination following the Colonial Course, showing the scholastic standard they have reached in their own countries, are then studied by a special 'Commission' set up by the Colonial Minister and this 'Commission' decides as to the grade of school in the Congo which the missionary is qualified to teach and for which subsidies will be granted. The representative in Belgium of the Protestant Missions in the Congo has been made a member of this 'Commission' and the Government acts through him on behalf of the Protestant missionaries seeking qualification.

Missionaries who were in the Congo prior to I January 1930 and who have been given a satisfactory 'Attestation' by a State inspector as to their knowledge of French and ability to teach, need only come to Belgium for three months and make contact with Belgian schools. Those who were in the Congo prior to I January 1945 and who have a similar 'Attestation' need only come for six months. These need only take those subjects of the Colonial Course which deal with Belgium and their attendance at an 'école normale' is reduced to three months.

Different courses of study are organized for medical missionaries and include a course of Tropical Medicine.

Over 900 Protestant missionaries of Congo missionary societies have studied in Belgium for various periods during the past five years.

(communicated by the Rev. H. W. Wakelin Coxill)

\section{Margaret Wrong Prize}

IN the competition for I950, which was open to competitors from Southern Sudan, Somaliland, Uganda, Tanganyika, Zanzibar, and the Belgian Congo, the silver medal and prize of fs was awarded to Gabriel-Adrien Ngbongbo of Stanleyville for a novel written in French and entitled Abunawazi le méchant. 